\title{
Phytoplankton diversity and strategies in regard to physical disturbances in a shallow, oligotrophic, tropical reservoir in Southeast Brazil
}

\author{
$\mathrm{M}^{\mathrm{a}}$ Rosélia M. Lopes ${ }^{1}$, Carla Ferragut ${ }^{2}$ and Carlos E. M. Bicudo ${ }^{2, *}$ \\ ${ }^{1}$ Universidade Federal do Acre, Departamento de Ciências da Natureza, BR-364, km 4, 69915-900 Rio Branco, \\ AC, Brasil. \\ ${ }^{2}$ Instituto de Botânica, Seção de Ecologia, Caixa postal 3005, 01061-970 São Paulo, SP, Brasil. \\ * Corresponding author: cbicudo@ terra.com.br
}

Received: 4/9/08 Accepted: 19/1/09

\begin{abstract}
Phytoplankton diversity and strategies in regard to physical disturbances in a shallow, oligotrophic, tropical reservoir in Southeast Brazil

The IAG Lake is a small, oligotrophic, and shallow reservoir located in the Parque Estadual das Fontes do Ipiranga Biological Reserve, south of Municipality of São Paulo, southeast Brazil. The study of the phytoplankton community dynamics is based on samples collected along the vertical profile of the water column in the pelagic region of the reservoir $\left(Z_{\max }=4.7 \mathrm{~m}\right), 3$ times a day ( $7 \mathrm{~h}, 13 \mathrm{~h}$, and $19 \mathrm{~h}$ ) during 7 consecutive days of the dry period (20-26 August 1996) and of the rainy period (2228 January 1997), but at 5 depths during the dry period and at 4 depths during the rainy one. The relationships among species richness, diversity, evenness, and dominance were discussed within the Connell's Intermediate Disturbance Hypothesis (IDH). The responses of the descriptive species in the community and C-R-S strategies were studied. The variation of the mixing zone was the main factor responsible for the changes in the community structure as well as for the maintenance of the diversity during both climate periods. The disturbance was considered of high frequency during the dry period and of intermediate frequency during the rainy one. The diversity was higher during the rainy period, confirming the IDH, at least during the present study. Peridinium gatunense Nygaard was dominant in most sample units during the dry period. During the rainy one, Chlamydomonas debaryana Goroschankin and Oocystis lacustris Chodat were the species that contributed the most. Regarding the functional groups, S-strategists dominated the dry period, differing from the rainy one, when the functional diversity was higher. In conclusion, changes in the phytoplankton community structure were well explained by Connell's IDH.
\end{abstract}

Key words: Biological indices, intermediate disturbance hypothesis, phytoplankton, thermal stratification and mixing.

\section{RESUMEN}

Diversidad y estrategias del fitoplancton frente a las perturbaciones físicas en un embalse somero, oligotrófico, tropical en sureste del Brasil

El lago IAG es un embalse pequeño, oligotrófico y somero, ubicado en la Reserva Biológica del Parque Estadual das Fontes do Ipiranga, Sur de la Municipalidad de São Paulo, sureste del Brasil. El estudio de la dinámica de la comunidad fitoplanctónica está basado en muestras colectadas al largo del perfil vertical de la columna de agua en la región pelágica del embalse $\left(\mathrm{Z}_{\text {max }}=4.7 \mathrm{~m}\right), 3$ veces al día $(7 \mathrm{~h}, 13 \mathrm{~h}$ y $19 \mathrm{~h})$ durante 7 días consecutivos de los períodos seco (20-26 Agosto 1996) y húmedo (22-28 Enero 1997), pero en 5 profundidades durante el período seco y en 4 durante el húmedo. Las relaciones entre riqueza de especies, diversidad, equitabilidad y dominancia fueron discutidos dentro de la Hipótesis de Connell de la Perturbación Intermedia (HPI). Las respuestas de las especies descriptoras de la comunidad y estrategias $C$ - $R$-S fueron estudiadas. La variación de la zona de mezcla fue el factor más importante en los cambios en la estructura de la comunidad así como para el mantenimiento de la diversidad durante los dos períodos climáticos. La perturbación fue considerada de frecuencia alta durante el período seco y de frecuencia intermedia durante el húmedo. La diversidad fue más alta durante el período de lluvias, confirmando la HPI, por lo menos en este estudio. Peridinium gatunense Nygaard fue dominante en 
la mayoría de las unidades de muestreo durante el período seco. Durante el período húmedo, Chlamydomonas debaryana Goroschankin y Oocystis lacustris Chodat fueron las especies que más contribuyeron. Considerando los grupos funcionales, los estrategas $S$ dominaron el período seco, a diferencia del periodo húmedo, cuando la diversidad funcional fue más alta. Concluyendo, los cambios en la estructura de la comunidad del fitoplancton fueron bien explicados por la HPI de Connell.

Palabras clave: Índices biológicos, Hipótesis de la Perturbación Intermedia, fitoplancton, estratificación térmica y mezcla.

\section{INTRODUCTION}

Algal community diversity may be used to characterize its structure, which is determined by the number of species present, their physiological properties and genetic potential, the physical and chemical environmental characteristics, herbivory, and parasitism. The diversity depends on the number of species that constitute the community as well as on its evenness (Elber \& Schanz, 1989). Diversity is a measure of which part of the biomass is distributed among species, as well as how that biomass is distributed in the environment (evenness) (Reynolds, 1997). It may decrease by reducing either the number of species or the evenness (Padisák, 1993). The diversity is directly related to the community's responses to environmental disturbances, and the Intermediate Disturbance Hypothesis (IDH). The Intermediate Disturbance Hypothesis states that nondisturbed or highly disturbed communities develop low diversity; and that disturbances of intermediate frequency and intensity are needed to maintain diversity, i.e. the number of species is at its highest when disturbance frequency and intensity are intermediate (Connell, 1978).

Reynolds (1988a) quantified the number of hours needed for the different scales of disturbance considering that if a disturbance lasts just a few hours $(<20 \mathrm{~h})$, i.e. it is lower than that of the algal generation time, meaning that the frequency of disturbance is low. If it is greater than $200 \mathrm{~h}$ or equivalent to more than 8 days, it is high. And if it lasts between 20 and $200 \mathrm{~h}$ or between 3 and 8 days, it is considered to be intermediate. According to Padisák (1993), daily samplings are needed to understand IDH, i.e. if the intermediate disturbance variation lasts for about 8 days, studies based on daily samplings would be vital for its demonstration.

Measuring the disturbance is somewhat problematic since phytoplankton under natural conditions is subjected to different types of disturbances that are difficult to quantify. There is no universal common scale for estimating changes in physical features, nutrient availability or grazing pressure. However, disturbance impact can be evaluated by the responses obtained from biological variables (Sommer, 1993). The species diversity index is the most used biological response for evaluation of IDH in the phytoplankton community (ex. Rojo \& Alvarez-Cobelas, 1993; Sommer, 1995; Flöder \& Sommer, 1999).

The application of Connell's IDH is important to understand the phytoplankton community organization as a path towards species diversity maintenance and pelagic ecosystem productivity (Reynolds, 1993). Experimental studies were designed to support IDH, bringing to light the direct relationship between diversity and disturbances intensity and frequency (ex. Robinson \& Sandgren, 1986; Sommer, 1995; Flöder \& Sommer, 1999). Non experimental studies directed towards validation or application of the IDH to phytoplankton communities were carried out mostly in temperate systems (ex. Olrik \& Nauwerck, 1993; Padisák, 1993). In Brazil, Matsumura-Tundisi \& Tundisi (2005) attributed to IDH diversity variability of the Barra Bonita Reservoir plankton.

The present investigation aimed at evaluating the phytoplankton community responses to physical disturbances, mainly to water stratification and daily mixing cycles and, consequently, at explaining the high diversity observed in tropical systems. 


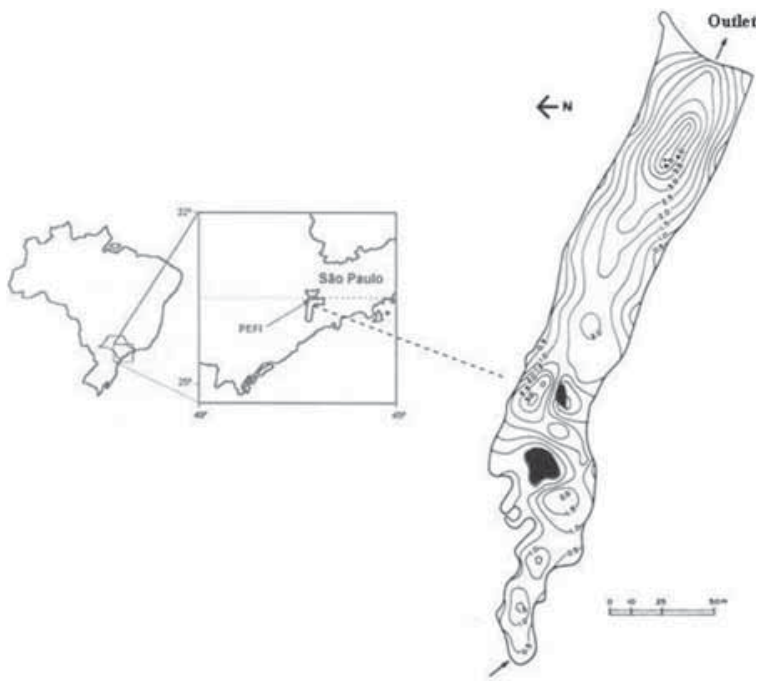

Figure 1. Location and bathymetric map of the IAG Lake with location of inflow (arrow), outlet and sampling station (v-4.5 m) (Bicudo, C. et al., 2002). Localización y mapa batimétrico del Lago IAG con localización de entrada (flecha), salida y estación de muestreo $(v-4.5 \mathrm{~m})$.

\section{MATERIAL AND METHODS}

Locally called 'IAG Lake', the system studied is, in fact, a small, shallow, oligotrophic reservoir located in the area of the Parque Estadual das Fontes do Ipiranga (PEFI) Biological Reserve, South of Municipality of São Paulo $\left(46^{\circ} 37^{\prime} \mathrm{W}, 2^{\circ} 39^{\prime} \mathrm{S}\right)$ under jurisdiction of the Science and Technology Center (CIENTEC, Centro de Ciência e Tecnologia) of the University of São Paulo (Fig. 1). According to Bicudo, C. et al. (2002), the reservoir's maximum depth is $4.7 \mathrm{~m}$, maximum length is $311.5 \mathrm{~m}$, maximum width is $45.5 \mathrm{~m}$, volume is $76652.64 \mathrm{~m}^{3}$ and mean retention time is 9.5 days.

Samplings were performed during 7 consecutive days at a single station (depth $4.7 \mathrm{~m}$ ) during two climatic periods: dry (20-26 August 1996) and rainy (22-28 January 1997). Environmental variables were studied in the whole water column at three different hours: $7 \mathrm{~h}, 13 \mathrm{~h}$ and $19 \mathrm{~h}$. There was no sampling at $19 \mathrm{~h}$ of January 22 due to very severe weather conditions.

Water samples $(n=2)$ were collected using a van Dorn sampler and transferred to polyethylene vials. For the thermal profile determina- tion, a Yellow Springs Instruments Multiple probe was used. Unfiltered water samples were frozen $\left(-20^{\circ} \mathrm{C}\right)$ and used for total nitrogen $(\mathrm{TN})$ and total phosphorus (TP) determinations (Valderrama, 1981) within at most 30 days from the collecting date. The methods used for the determination of the water physical characteristics are the same as in Lopes \& Bicudo (2001).

During the dry season, samples were collected at 5 fixed depths $(0.1,1,2,3$ and $4.5 \mathrm{~m})$. During the rainy season however, changes in the thermal gradient indicated the presence of a discontinuous layer (thermocline) in the water column. The strata sampled during the latter period were: $P_{1}(0.2-0.3 \mathrm{~m})$ above the discontinuous layer; $P_{2}$ (ca. $1.5 \mathrm{~m}$ ) upper limit of the discontinuous layer; $P_{3}(3-3.5 \mathrm{~m})$ inside the discontinuous layer; and $P_{4}(4.5 \mathrm{~m})$ bottom (ca. $0.2 \mathrm{~m}$ above sediments).

Samples for phytoplankton quantitative analyses were collected at each reservoir stratum with a van Dorn bottle, stored in $300 \mathrm{ml}$ glass vials, fixed and preserved in acetic lugol solution, and immediately stored in darkness at room temperature. Quantitative determination of phytoplankton was carried out according to Utermöhl (1958) and sedimentation time in chamber following Lund et al. (1958). Countings were performed using a Zeiss Jena-Sedival (400×) inverted microscope. The biovolume of each species was obtained by comparing them with the volume of a geometric solid, taken either isolated or combined, that would mostly resemble the cell form (Hillebrand et al., 1999; Sun \& Liu, 2003).

Statistical indices referring to the community structure, such as diversity index

$$
H^{\prime}=\sum p i \cdot \log _{2} p i
$$

(Shannon \& Weaver, 1963), evenness

$$
E=H^{\prime} / \log _{2} S
$$

(Odum, 1983) and dominance

$$
D=\sum p i^{2}
$$

(Simpson, 1949) were calculated based on the algal biovolume.

The concept of C-R-S functional groups (Reynolds, 1984a, 1988b, 1997) was applied to the phytoplankton community. 

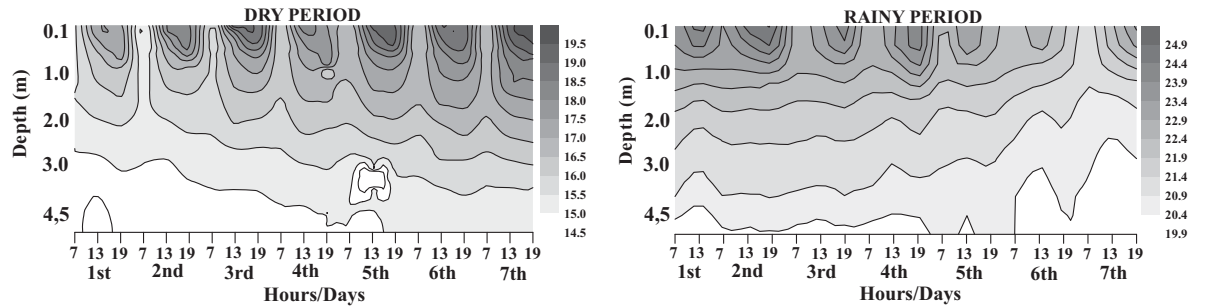

Figure 2. Depth and time diagram of the water temperature $\left({ }^{\circ} \mathrm{C}\right)$ isolines at the IAG Lake during the dry and rainy periods. Diagrama de tiempo y profundidad de las isolíneas de temperatura del agua $\left({ }^{\circ} \mathrm{C}\right)$ del Lago IAG durante los períodos seco y lluvioso.

Statistical treatment of the data was performed using descriptive analysis and arithmetic average and median as measurements of central tendency. Absolute dispersal degree of data was calculated using the standard deviation, and relative dispersal through the Pearson variation coefficient (VC). It aimed at establishing the degree of significance of values obtained for the biological indices and the distinct sampling depths and hours in each sampling day; Variance Analysis (ANOVA) with a level of significance of about $5 \%$ for each sampling day was performed using Minitab for Windows, version 13.0.

\section{RESULTS}

Based on physical and chemical water characteristics, the IAG Lake is classified as oligotrophic (Bicudo, D. et al., 2002). Despite the reservoir's shallowness $\left(Z_{\max }=4.7 \mathrm{~m}\right)$, it was possible to detect thermal stratification during both study periods. Stratifications were temporal during the dry period, with night circulation (Fig. 2) and long lasting during the rainy period, with no evidence of night circulation, except for the $7 \mathrm{~h}$ of 28 January 1997 (Fig. 2). The depth of the mixing zone was shallower during the rainy period, indicating greater water column stability in the latter period.

The vertical distribution of the TN and TP concentration tended to homogeneity during the entire dry period, being however stratified during the rainy period (Fig. 3). Rupture of TP stratified profile was observed at the $7^{\text {th }}$ sampling day of the rainy period (Fig. 3). A comparison between the dry and rainy periods showed that TN and TP concentrations were always greater during the latter period.
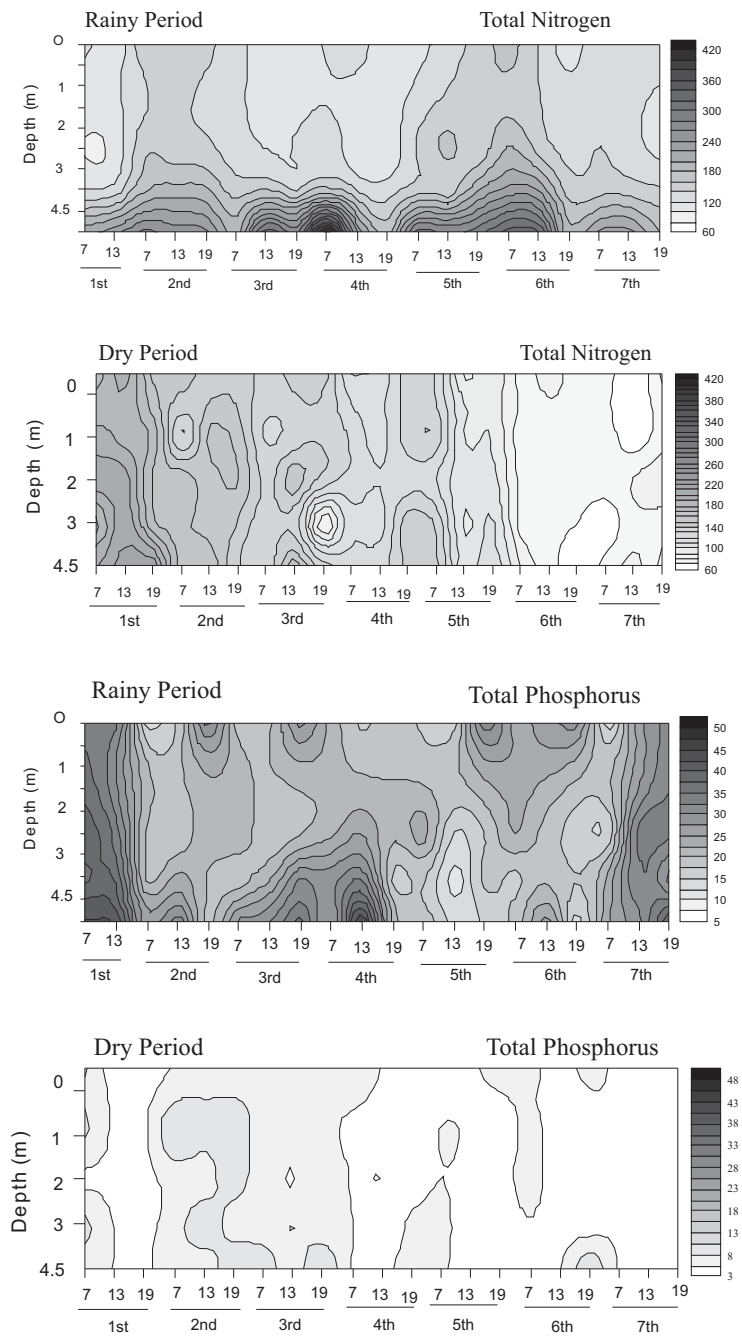

Figure 3. Depth and time diagram of the total nitrogen $\left(\mu \mathrm{g} \cdot \mathrm{L}^{-1}\right)$ and total phosphorus $\left(\mu \mathrm{g} \cdot \mathrm{L}^{-1}\right)$ isolines at the IAG Lake during the dry and rainy periods. Diagrama de tiempo y profundidad de las isolíneas de nitrógeno total $\left(\mu \mathrm{m} \cdot L^{-1}\right)$ y fósforo total $\left(\mu \mathrm{m} \cdot \mathrm{L}^{-1}\right)$ en el Lago IAG durante los períodos seco y lluvioso. 

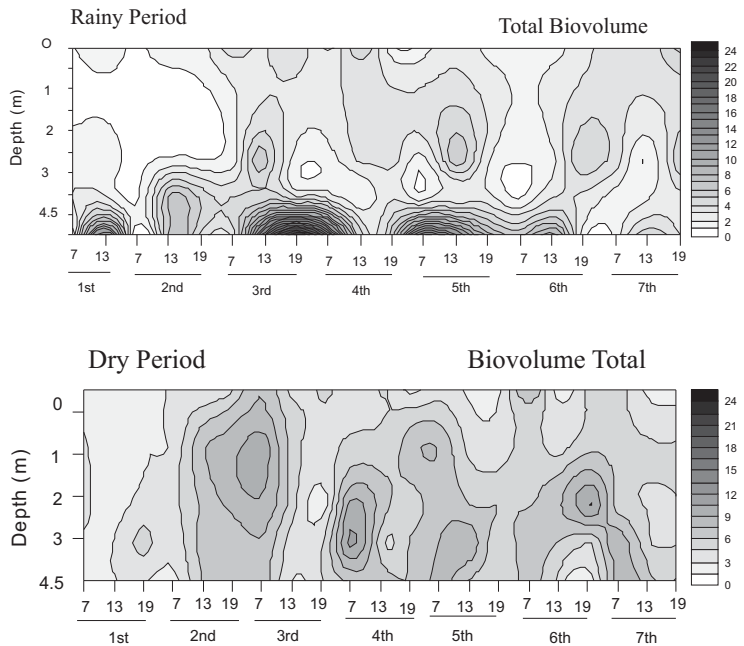

Figure 4. Depth and time diagram of the total biovolume $\left(\mathrm{mm}^{3} \cdot \mathrm{L}^{-1}\right)$ isolines of the phytoplankton species at the IAG Lake during the dry and rainy periods. Diagrama de tiempo y profundidad de las isolineas de biovolumen total $\left(\mathrm{mm}^{3} \cdot \mathrm{L}^{-1}\right)$ de las especies del fitoplancton en el Lago IAG durante los periodos seco y lluvioso.

During the dry period, vertical and temporal distribution of phytoplankton total biovolume tended to homogeneity, whereas during the rainy one they were very much heterogeneous (Fig. 4). Vertically, great total biovolume values at the deepest layers of the reservoir were detected, mainly during the rainy period. Variation coefficient $\mathrm{Q}$, calculated using total biovolume average at each time, showed that variability among hours was lower during the dry period $(\mathrm{VC}=17-49 \%)$ than in the rainy one $(\mathrm{VC}=28-132 \%)$. Thus, the rainy period presented total biomass distribution that had the greatest heterogeneity, with a reduction of total biovolume values after the $7^{\text {th }}$ day of the rainy period (Fig. 4 ).
Considering the species' diversity index spatial and temporal scales during both study periods (Figs.4-5), highest values were detected during the rainy period. Vertical variation (depths) at each sampling time during the dry period was low when compared to the rainy one, presenting a variation coefficient of 1.6-25\% and 9.9-52\%, respectively.

During the dry period, phytoplankton diversity spatial distribution was more homogeneous, not showing significant differences between depths; differences were significant mainly between sampling hours and days (Table 1, Fig. 5). Thus, during the dry period, despite diversity having a higher temporal variability (hours and days), its vertical distribution tended to homogeneity. This was different during the rainy period, when diversity spatial distribution was quite heterogeneous, tending to the smallest values at the deepest layers of the reservoir, always below the thermocline (Fig. 6). During the latter period, diversity values pointed out for significant differences among depths, but not among days and hours (Table 1).

During the dry period, evenness values did not show significant differences among depths, differences being noticed among hours and days (Table 1). During the rainy period, evenness values were significant only among depths (Table 1). Considering the daily average of the evenness values, it was observed that homogeneous distribution of species was always greater during the rainy period (Fig. 7).

During both the dry and the rainy periods, species richness variation was not significantly different among sampling hours, thus demonstrating that phytoplankton vertical distribution was uniform during the day (Table 1, Fig. 7). Spe-

Table 1. Results of ANOVA used to establish the level of significance of the vertical and temporal variation of the diversity $\left(\mathrm{H}^{\prime}\right)$, evenness (E), number of species (S), and dominance (D) during the dry and rainy periods. Resultados del ANOVA utilizado para establecer el nivel de significancia de la variación vertical y temporal de la diversidad $\left(H^{\prime}\right)$, equitabilidad (E), número de especies (S) e domináncia $(D)$ durante los períodos seco y lluvioso.

\begin{tabular}{|c|c|c|c|c|c|c|c|c|c|c|c|c|c|}
\hline & & \multicolumn{4}{|c|}{ Depth } & \multicolumn{4}{|c|}{ Hour } & \multicolumn{4}{|c|}{ Day } \\
\hline & & $\mathbf{H}^{\prime}$ & $\mathbf{S}$ & $\mathbf{E}$ & D & $\mathbf{H}^{\prime}$ & $\mathbf{S}$ & $\mathbf{E}$ & D & $\mathbf{H}^{\prime}$ & $\mathbf{S}$ & $\mathbf{E}$ & D \\
\hline \multirow{2}{*}{ Dry } & $\mathrm{F}$ & 1.24 & 2.25 & 2.02 & 0.720 & 4.65 & 0.25 & 4.52 & 3.53 & 3.39 & 3.64 & 3.28 & 2.38 \\
\hline & $p$ & 0,300 & 0.069 & 0.098 & 0.577 & 0.012 & 0.778 & 0.013 & 0.033 & 0.004 & 0.003 & 0.006 & 0.034 \\
\hline \multirow{2}{*}{ Rainy } & $\mathrm{F}$ & 8.87 & 1.29 & 10.42 & 8.13 & 0.45 & 0.39 & 0.65 & 0.38 & 1.14 & 3.21 & 0.60 & 1.59 \\
\hline & $p$ & 0.000 & 0.285 & 0.000 & 0.000 & 0.637 & 0.678 & 0.525 & 0.682 & 0.348 & 0.007 & 0.731 & 0.163 \\
\hline
\end{tabular}




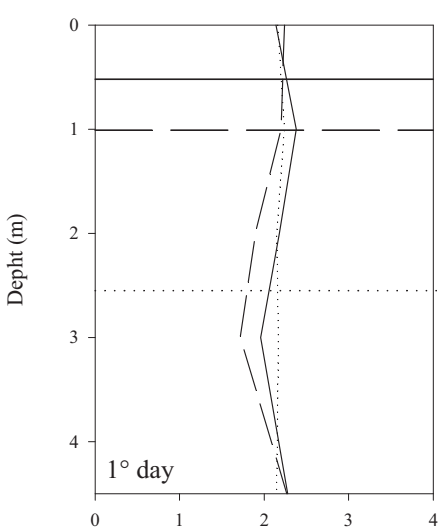

Diversity Species

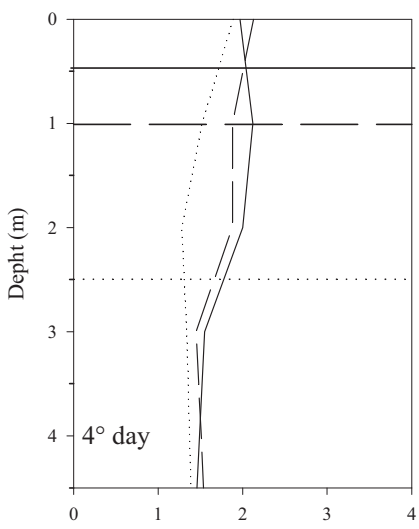

Diversity Species

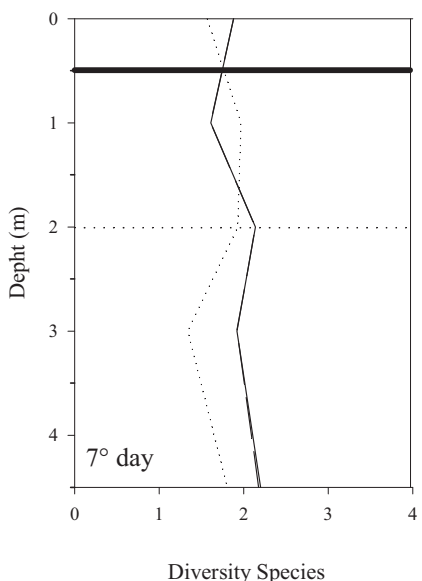

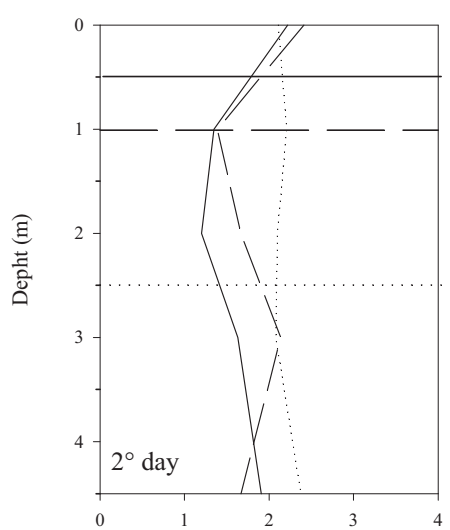

Diversity Species

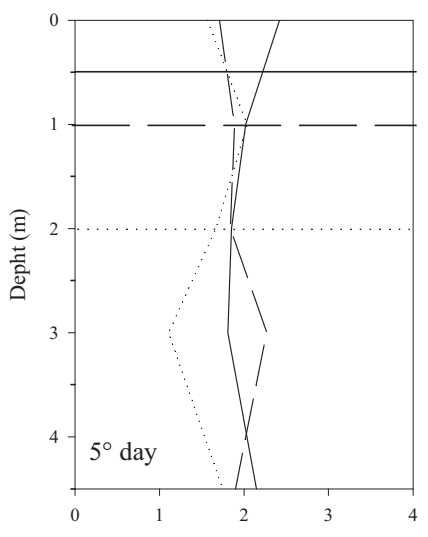

Diversity Species
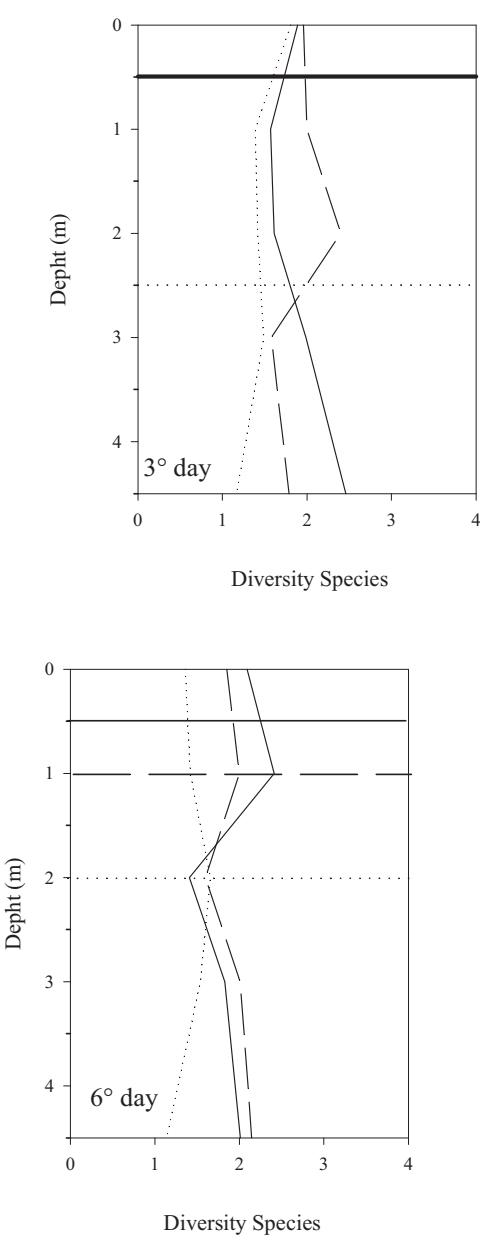

$7 \mathrm{~h}$

$13 \mathrm{~h}$

$19 \mathrm{~h}$

Figure 5. Vertical variation of the diversity index (bits $\cdot \mathrm{mg}^{-1}$ ) and mixing zone location during the dry period at $7 \mathrm{~h}(\ldots \ldots . . . .),. 13 \mathrm{~h}$

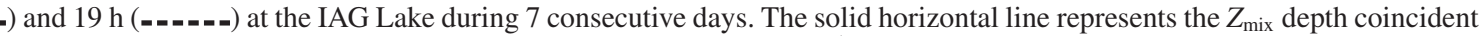
in 2 or 3 sampling hours. Variación vertical del índice de diversidad (bits $\cdot \mathrm{mg}^{-1}$ ) y ubicación de la zona de mezcla durante el período seco a las $7 \mathrm{~h}$ (..........), $13 \mathrm{~h}$ (_ $) 19$ h (--_--) en el Lago IAG durante 7 días consecutivos. La línea sólida horizontal representa la profundidad de la $\mathrm{Z}_{\text {mix }}$ coincidente en 2 o 3 horas de muestreo. 

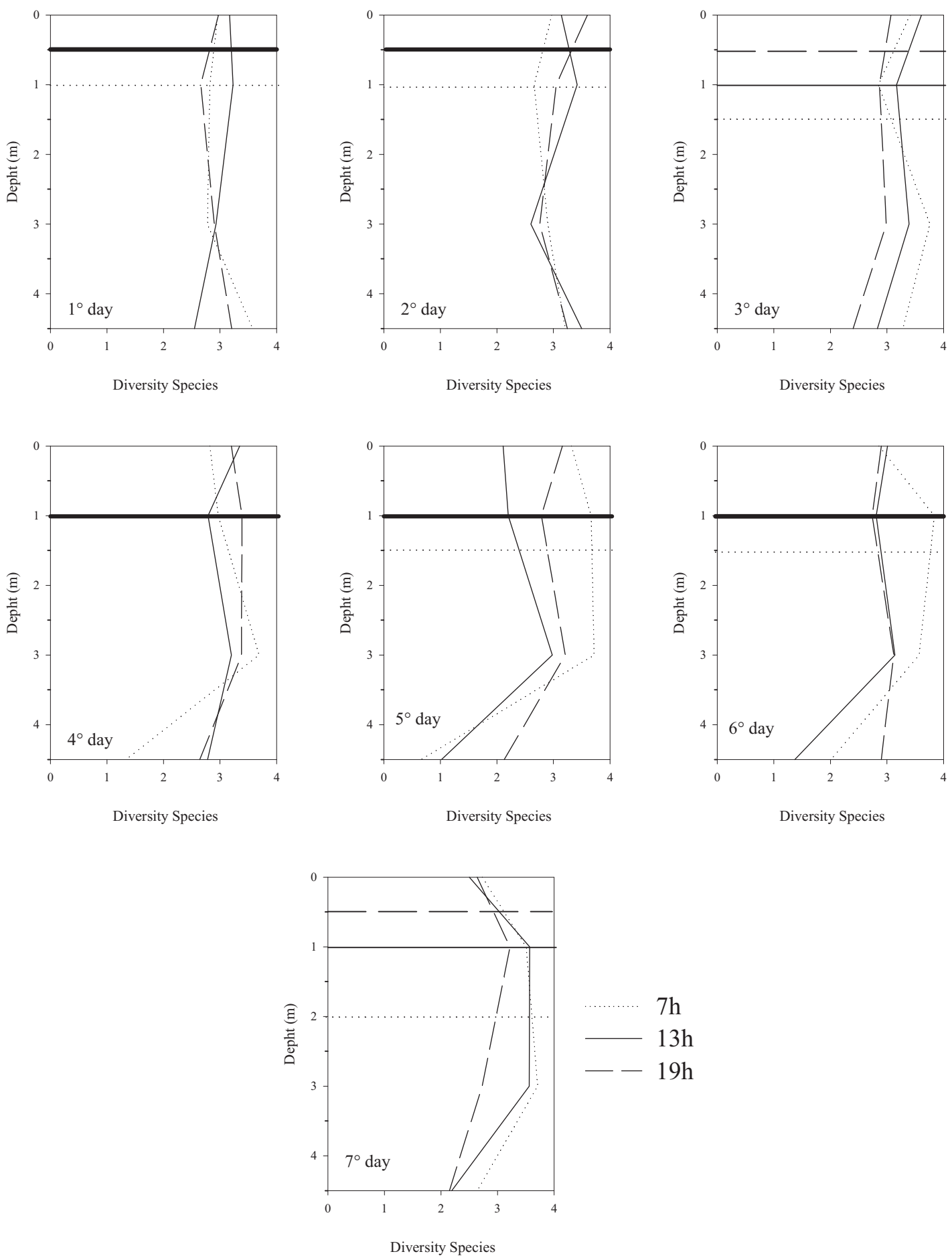

Figure 6. Vertical variation of the diversity index (bits $\left.\cdot \mathrm{mg}^{-1}\right)$ and mixing zone location during the rainy period at $7 \mathrm{~h}(. . . . . . . .$.$) ,$

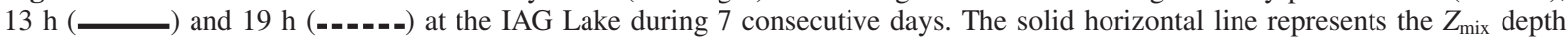
coincident in 2 or 3 sampling hours. Variación vertical del índice de diversidad (bits $\cdot \mathrm{mg}^{-1}$ ) y ubicación de la zona de mezcla durante el período lluvioso a las $7 \mathrm{~h}$ (..........), $13 \mathrm{~h}$ (_) y $19 \mathrm{~h}$ (--.-.-) en el Lago IAG durante 7 días consecutivos. La línea sólida horizontal representa la profundidad de la $\mathrm{Z}_{\text {mix }}$ coincidente en 2 o 3 horas de muestreo. 
a.

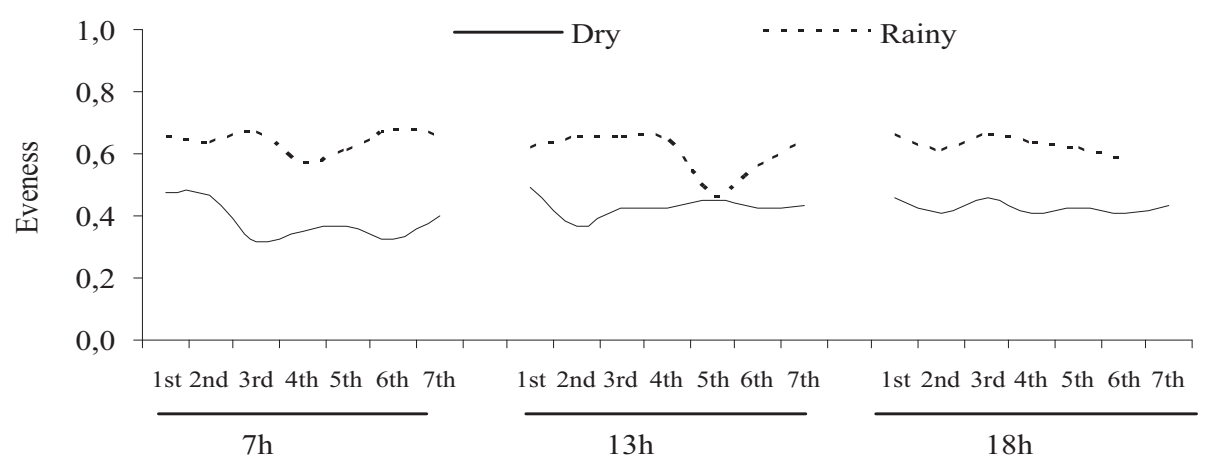

b.

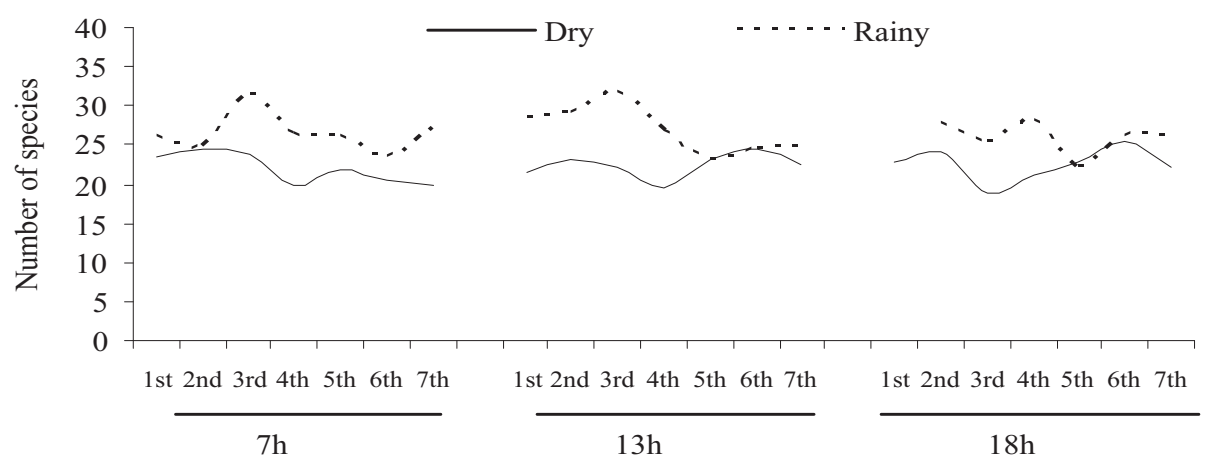

c.

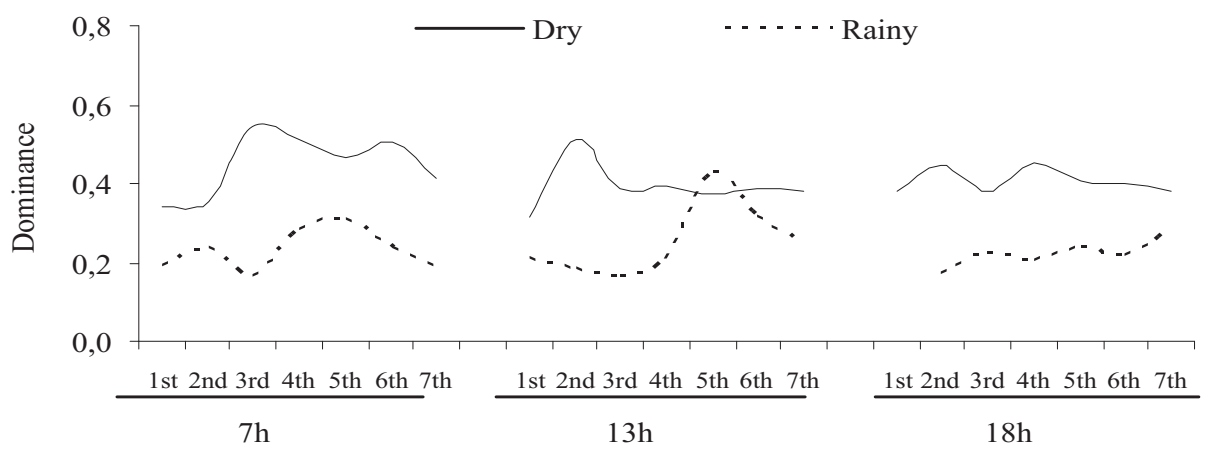

Figure 7. Daily mean and standard deviation $(n=15)$ of evenness (a), number of species (b) and dominance index (c) during 7 consecutive days and 3 different times at the IAG Lake during the dry (_) and rainy (-_-_-_) periods. Media diaria y desvio estándar $(\mathrm{n}=15)$ de la equitabilidad $(a)$, del número de especies $(b)$ y del índice de dominancia (c) durante 7 días consecutivos y 3 épocas distintas en el Lago IAG durante los periodos seco (

y lluvioso (-1-n-n).

cies richness vertical variation was small during both study periods (dry: $\mathrm{VC}=4-17 \%$; rainy: $\mathrm{VC}=5-25 \%$ ), being usually greater during the rainy period (Fig. 7). The number of species varied between 19 and 26 during the dry period and between 18 and 32 during the rainy one. 
Dominance index varied little at hourly and daily scales during the two study periods, having little influence on diversity and species richness. The dominance index showed very homogeneous spatial and temporal distributions, indicating no significant differences between sampling depths, hours and days, except for depth during the rainy period. Higher dominance values were detected during the dry season, in average 1.3 to 2.6 times higher than during the rainy season (Fig. 7).

During the two study periods, simple regression analysis showed that species diversity was more affected by evenness than by species richness (Fig. 8).

Considering phytoplankton spatial and temporal distribution (hourly and daily), based on the average biovolume, the main community des-

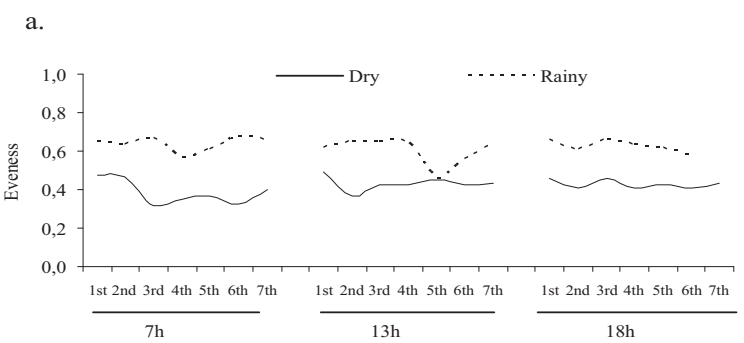

b.

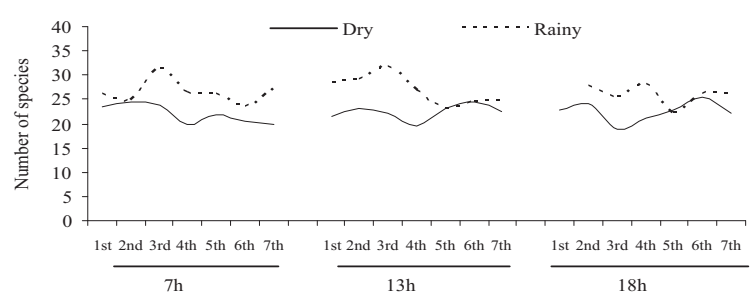

c.

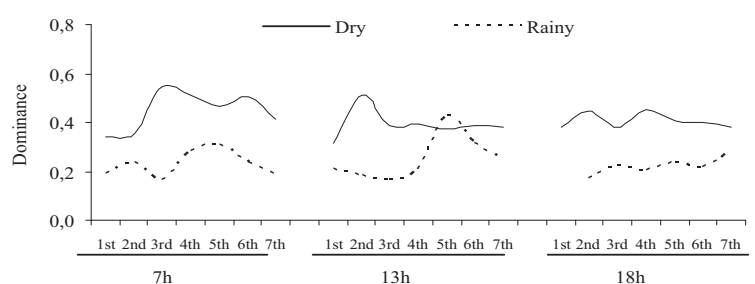

Figure 8. Degree of association between diversity (bits $\cdot \mathrm{mg}^{-1}$ ), evenness and diversity (bits $\cdot \mathrm{mg}^{-1}$ )-number of species (numerical richness) during 7 consecutive days and 3 different times during the dry and rainy periods. Grado de asociación entre diversidad (bits $\cdot \mathrm{mg}^{-1}$ ), equitabilidad y diversidad (bits $\cdot \mathrm{mg}^{-1}$ )-número de especies (riqueza numérica) durante 7 días consecutivos y 3 épocas distintas de 2 períodos. criptive species were Peridinium gatunense $\mathrm{Ny}$ gaard and Oocystis lacustris Chodat, whose contribution during the dry period was, respectively, $54.4 \%$ and $29.8 \%$ of the total biovolume (Fig. 9). Emphasis should also be given to the dominance of $P$. gatunense in $58 \%$ of the dry period sampling units (105 sampling units), and to its abundance in all the remaining ones. During the rainy period, five species were considered descriptive of the community, namely Chlamydomonas debaryana Goroschankin, Oocystis lacustris, P. gatunense, Frustulia crassinervia (Brébisson) LangeBertalot \& Krammer, and Pteromonas sp., which altogether had an average contribution of $66.7 \%$ or, individually, $24 \%, 12 \%, 12 \%, 10 \%$ and $5 \%$ of the total biovolume. Considering species representativeness in the community structure, during the rainy period 12 species represented together $81 \%$, whereas during the dry one, just $P$. gatunense and $O$. lacustris together represented $80 \%$.

The phytoplankton community descriptive species during the dry period $-O$. lacustris and $P$. gatunense - reduced, respectively, by 6 and 3 times their average biovolume during the rainy period.

Application of the C-R-S functional group approach sensu Reynolds (1984a, 1988b, 1997) indicated dominance of S-strategists during the entire dry period, contributing between $81 \%$ and $93 \%$ to the community. However, during the rainy period, the phytoplankton community had the participation of all three kinds of strategists, particularly of C-strategists, whose representativeness varied from $23 \%$ to $83 \%$ (Fig. 10).

\section{DISCUSSION}

Disturbances are mainly stochastic abiotic events that result in distinct abrupt changes in the community taxonomical composition, directing its internal organization and ecological equilibrium. Such events include the time scale and the frequency of the algal generation time (Reynolds 1988a). Connell's (1978) IDH was adapted to the phytoplankton by Reynolds (1988a) that stated that maximum diversity is reached under intermediate disturbance condition and frequency. Among others, Reynolds (1995), Sommer (1995) and Flöder \& Sommer 

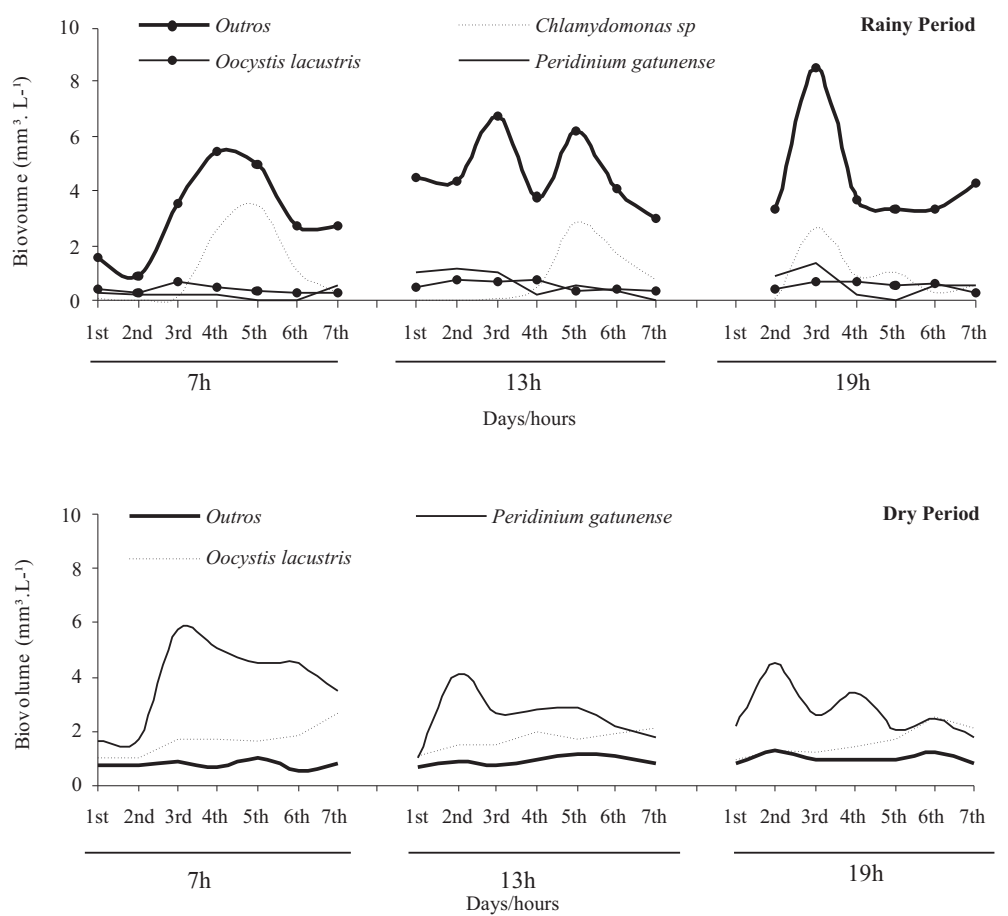

Figure 9. Hourly changes of the phytoplankton's total biovolume $\left(\mathrm{mm}^{3} \cdot \mathrm{L}^{-1}\right)$ and of the specific biovolume of the community's descriptive species during 7 consecutive days during the dry and rainy periods. Cambios horarios del biovolumen fitoplanctónico total $\left(\mathrm{mm}^{3} \cdot \mathrm{L}^{-1}\right)$ y del biovolumen específico de las especies descriptoras de la comunidad durante 7 días consecutivos de los períodos seco y lluvioso.
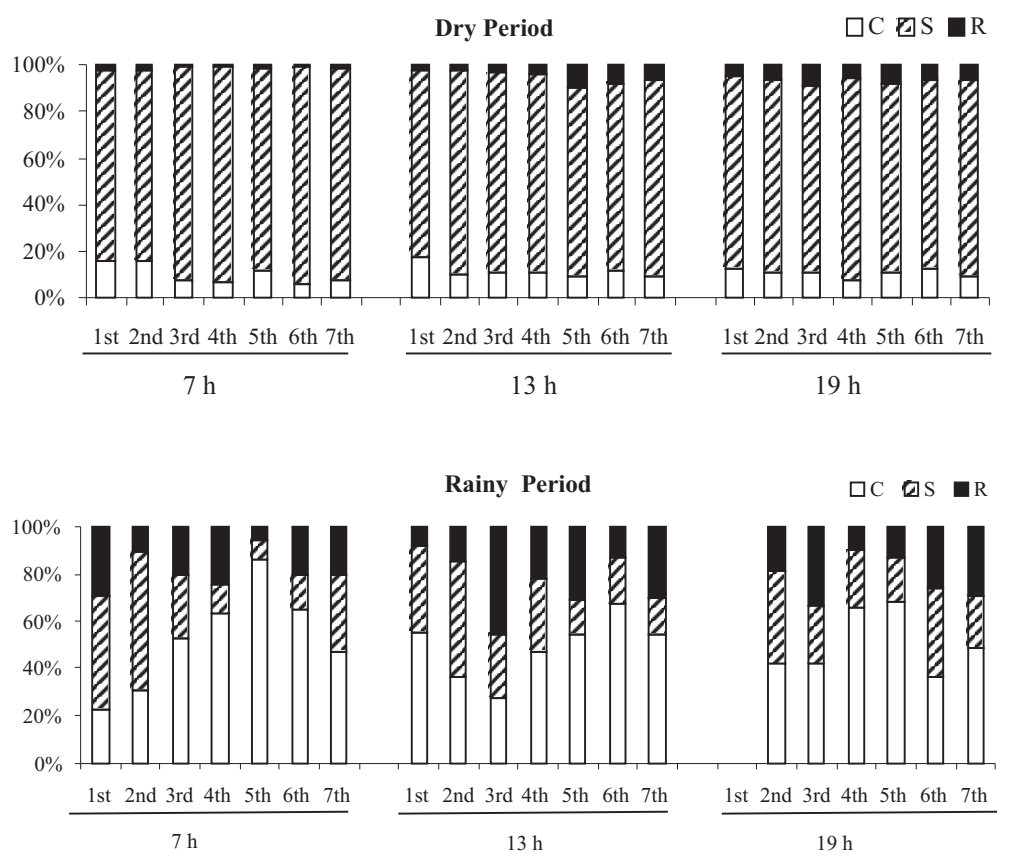

Figure 10. Variation of C-R-S (sensu Reynolds) functional groups during 7 consecutive days during the dry and rainy periods. Variación de los grupos funcionales $C$-R-S (de acuerdo con Reynolds) durante 7 días consecutivos de 2 períodos: seco y lluvioso. 
(1999) considered that IDH is a good explanation for Hutchinson (1961) 'plankton paradox'. According to Kalff (2002), IDH is an attempt to reconcile the most recent interpretation of non-equilibrium with the old one of equilibrium, simply because the organizational status of a community is the result of a progress towards equilibrium after the last disturbance. It is consensual that different disturbance levels may act differently on the phytoplankton community organization. Thus, application of the IDH may contribute to the understanding of complex structural changes in the community, mainly in the tropical region were they are not yet well understood.

The IAG Lake is subjected to physical disturbances that could, afterwards, interfere in the phytoplankton community composition, biomass and diversity. According to Eloranta (1993), an increase of the mixing zone depth, changes in water transparency and turbidity, and nutrient availability are factors that affect the community structure. An increase of the mixing zone depth can be interpreted as a disturbance that would re-establish the phytoplankton community succession process (Lewis, 1978; Reynolds, 1984a). The diversity of phytoplankton communities is probably maintained by continuous temporal changes that seem to keep such communities in a continuous succession process.

According to Sommer et al. (1993), an increase of the mixing zone depth can be one ideal indicator of physical disturbance in stratified environments. Among the factors that act as disturbance agents at the IAG Lake, the most directly connected with phytoplankton community responses is the water column stratification and mixing (Lopes \& Bicudo, 2001; Lopes et al., 2005). Such a process is responsible for an important variation of the mixing zone depth that allowed identification of atelomixis in the IAG Lake during the dry period (Lopes et al., 2005). Therefore, in the present study, the variation of the mixing zone is considered a disturbance factor.

As in Reynolds (1988a), the depth of the mixing zone at the IAG Lake was considered a disturbance factor of low frequency during the dry period due to circulation occurring at intervals shorter than $20 \mathrm{~h}$. During the rainy period (20-
$200 \mathrm{~h}$ or equivalent to $1-8$ days) it was considered of intermediate frequency due to the mixing zone depth increase during the $7^{\text {th }}$ sampling day, at 07:00 h, as a result of the circulation that occurred during the proceeding night. In other words, the dry period was considered a high frequency physical disturbance one, which took place at maximum intervals of 12 hours, while the rainy period was considered an intermediate frequency period because only after six days a strong enough physical disturbance occurred that modified the mixing zone depth. Observation allowed us to deduce that such a circulation and the consequent increase of the mixing zone depth occurred less frequently during the rainy period than during the dry period. Therefore, disturbance was classified as intermediate frequency.

The period of intermediate frequency disturbance (rainy) was characterised by simultaneous thermal and chemical stratification presently identified by stratification of both TN and TP concentration and DO profile (Lopes \& Bicudo, 2001). Conversely, vertical distribution of those same variables was homogeneous during the high disturbance period (dry). It should also be mentioned that the highest TN and TP availabilities occurred during the rainy period.

The phytoplankton community structure at the IAG Lake differed substantially in terms of total biovolume between the two study periods. During the rainy one, total biovolume remained stratified during the seven sampling days, presenting greater biomass production below the mixing zone (within the thermocline). On the contrary, during the dry period its vertical distribution was homogeneous. Consequently, total biovolume reflected stratification and mixing conditions, indicating the greater biomass production in the metalimnion under intermediate disturbance conditions.

The species' diversity provides information about the phytoplankton community internal organization (Margalef, 1974). Comparing evenness and species richness in each stage (same population generation time) under different conditions (dry and rainy) it is possible to evaluate the climate impact on phytoplankton diversity. Highest diversity, evenness, and species richness values were measured during the rainy period, the 
disturbance frequency being intermediate. Diversity was high during both periods of the present study when compared to other ones carried out at the PEFI Biological Reserve area (Crossetti \& Bicudo, 2005). Such results very well demonstrate the role of physical high frequency disturbances, such as night circulation, on preventing an increase in the phytoplankton diversity. Atelomixis associated with high frequency disturbance explains the existence of the smallest diversity, evenness and species richness values at the reservoir during the dry period.

During the dry period, the mixing zone depth increase resulting from night circulation suggested the presence of a high frequency disturbance condition. Under this condition, the phytoplankton community was characterised for its temporal high diversity and evenness variability (hours and days). During the intermediate disturbance period (rainy), the same biological indices revealed greater vertical variability, showing no significant difference in the temporal scale. Consequently, species diversity and evenness responded differently to the different frequency levels of disturbance.

Since diversity refers to number of species and its evenness, such components exhibited an irregular distribution pattern throughout the two study periods due to biomass oscillation in the reservoir. It was possible to observe that during the mixing period (dry period) P. gatunense dominance was detected in most sampling units. Other studies carried out in the IAG Lake reported a high density of $P$. gatunense during the mixing period (Lopes et al., 2005; Oda \& Bicudo, 2006). In the subtropical Lago Kinneret, $P$. gatunense bloom declined during the stratification period (Zohary et al., 2000). During the same period, it was also observed that death rates proceeded a mass sedimentation flux of Peridinium (Viner-Mozzini et al., 2003). Presently, a condition of high frequency disturbance (night circulation) documented during the dry period favoured the dominance of the S-strategist $P$. gatunense.

During the rainy period (intermediate disturbance), species diversity and evenness highest values were confirmed by the phytoplankton community taxonomical structure. Despite the persistence of $P$. gatunense and $O$. lacustris among the main community descriptive species, the increase in participation of other species such as, for example, Chlamydomonas debaryana, Pteromonas sp. and Frustulia crassinervia was evident. Frustulia is usually related to the bentonic habitat (Siver \& Baskette, 2004), but it also occurs in the phytoplankton of shallow lakes (Ziller \& Economou-Amilli, 1998; Negro et al., 2003; Cardoso \& Motta-Marques, 2004), possibly due to the reduction of loss by sedimentation under mixing conditions (Wíllen, 1991) and/or re-suspension of the species from the bottom (Cardoso \& Motta-Marques, 2004). Emphasis should be put on $C$. debaryana among the most favoured species under the intermediate frequency disturbance condition, its population density being associated to the high TP values during the rainy period (Lopes et al., 2005). As a rule, Chlorophyceae are very much favoured under great nutrient availability conditions (HappeyWood, 1988). Consequently, under the intermediate frequency disturbance condition (rainy period) $P$. gatunense lost its competitive advantage, with a daily average contribution to the community reduced 2 to 19 times in relation to that of the dry period. Also, the participation of several other species (diversity increase), mainly of Chlorophyceae, was observed.

The modification in the phytoplankton community taxonomical structure confirmed results obtained by using biological indices, i.e. diversity increase and dominance index decrease during the intermediate disturbance period.

Considering the C-S-R triangle proposed by Reynolds (1984b, 1988b, 1997), the species identified for the IAG Lake clearly demonstrated that atelomixis (night circulation) conditions during the dry period favoured S-strategists (sensu Reynolds). According to Reynolds (1997), this functional group has the ability to explore nutrient depleted environments. It must be emphasized that during the dry period at the IAG Lake, nutrient availability was lower and its vertical distribution more homogeneous. On the other hand, during the rainy period, under more stable conditions at the reservoir (absence of night circulation during the entire $144 \mathrm{~h}$ study period), there was an increase in adaptive strategies diversity, mostly of C- 
strategists (sensu Reynolds), which are able to explore light and nutrient saturated environments (Reynolds, 1997). C-strategists were mostly represented by Chlorophyceae. According to Connell (1978), a community under an intermediate frequency disturbance condition may re-establish many times its pioneer species (C-strategists) and successfully competing populations may coexist. Consequently, maximum diversity would be met under an intermediate frequency disturbance condition. On the other hand, under a high frequency disturbance condition, few pioneer species may get established after each disturbance event, thus maintaining low diversity.

Based on the observations above, it is possible to state that the phytoplankton community at the IAG Lake presented a non-successional change, since physical disturbances such as loss of water column stability and increase of the mixing zone depth led to that sort of change in the species' composition (Sommer, 1991). According to the latter author, succession is the change in the species' composition resulting from intrinsic interactions under external non-disturbed conditions, i.e. under stability or increase of physical stability of the water column system.

The main disturbance factor in the IAG Lake was the depth variation of the mixing zone, which was not associated to the wind action on the water column, but to its daily cooling-heating cycle (atelomixis). Disturbance events (mixing zone depth) were considered of high frequency during the dry period and of intermediate frequency during the rainy one. Attributes of the phytoplankton community presently studied -species' diversity, evenness, and dominance and richness- were high during both study periods, but significantly higher during the rainy one. Finally, the present observations and the short term results from this investigation confirm the basis of the IDH in natural phytoplankton communities in a tropical ecosystem, thus showing that diversity was greater during the intermediate disturbance phase (rainy period). Limnological conditions also favoured evenness and species richness increase, besides inducing changes in the phytoplankton community structure at its descriptive species and functional groups level. Finally, it is clearly evident that the
IDH may be a powerful mechanism towards understanding the complex phytoplankton structural changes under spatial and temporal scales and thus, to proceed towards predictability.

\section{ACKNOWLEDGEMENTS}

We would like to thank CNPq, Conselho Nacional de Desenvolvimento Científico e Tecnológico (303876/2004-2) for partial financial support.

\section{REFERENCES}

BICUDO, C. E. M., C. F. CARMO, D. C. BICUDO, R. HENRY, A. C. S. PIÃO, C. M. SANTOS \& M. R. M. LOPES. 2002. Morfologia e morfometria de três reservatórios do PEFI. In: Parque Estadual das Fontes do Ipiranga (PEFI): unidade de conservação que resiste à urbanização de São Paulo. D. C. Bicudo, M. C. Forti \& C. E. M. Bicudo (Orgs.): 143-160. Ed. Secretaria do Meio Ambiente do Estado de São Paulo, São Paulo.

BICUDO, D. C., M. C. FORTI, C. F. CARMO, C. BOUROTTE, C. E. M. BICUDO, A. J. MELFI \& Y. LUCAS. 2002. A atmosfera, as águas superficiais e os reservatórios no PEFI: caracterização química. In: Parque Estadual das Fontes do Ipiranga (PEFI): unidade de conservação que resiste à urbanização de São Paulo. D. C. Bicudo, M. C. Forti \& C. E. M. Bicudo (Orgs.): 161-212. Ed. Secretaria do Meio Ambiente do Estado de São Paulo, São Paulo.

CARDOSO, L. de S. \& D. M. L. MOTTA-MARQUES. 2004. Seasonal composition of the phytoplankton community in Itapeva lake (north coast of Rio Grande do Sul-Brazil) in function of hydrodynamic aspects. Acta Limnol. Bras., 16: 401-416.

CONNELL, J. 1978. Diversity in tropical rain forests and coral reefs. Science, 199: 1304-1310.

CROSSETTI, L. O. \& C. E. M. BICUDO. 2005. Structural and functional phytoplankton responses to nutrient impoverishment in mesocosms placed in a shallow eutrophic reservoir (Garças Pond), São Paulo. Hydrobiologia, 541: 71-85.

ELBER, F. \& F. SCHANZ. 1989. The causes of change in the diversity and stability of phytoplankton communities in small lakes. Freshwat. Biol., 
21: 237-251.

ELORANTA, P. 1993. Diversity and succession of the phytoplankton in a small lake over a two-year period. Hydrobiologia, 249: 25-32.

FLÖDER, S. \& U. SOMMER. 1999. Diversity in planktonic communities: an experimental test of the intermediate disturbance hypothesis. Limnol. Oceanogr., 44: 1114-1119.

HAPPEY-WOOD, V. M. 1988. Ecology of freshwater planktonic green algae. In:, Growth and reproductive strategies of freshwater phytoplankton. C. D. Sandgreen (ed.): 175-226. Cambridge University Press, New York.

HILLEBRAND, H., D. DÜRSEKEN, D. KIRSCHIEL, U. POLLINGHER \& T. ZOHARY. 1999. Biovolume calculation for pelagic and benthic microalgae. J. Phycol., 35: 403-424.

HUTCHINSON, G. E. 1961. The paradox of the plankton. The American Naturalist, 95: 137-145.

KALFF, J. 2002. Limnology. Prentice Hall, New Jersey. 592 pp.

LEWIS, W. M. 1978. Analysis of succession in a tropical plankton community and a new measure of succession rate. Amer. Nat., 112: 401-414.

LOPES, M. R. M. \& C. E. M. BICUDO. 2001. Short term variation of physical characteristics of a shallow subtropical oligotrophic reservoir, southeast Brazil. Acta Limnol. Bras., 13: 87-98.

LOPES, M. R. M., C. E. M. BICUDO \& C. FERRAGUT. 2005. Short term spatial and temporal variation of phytoplankton in a shallow tropical oligotrophic reservoir, southeast Brazil. Hydrobiologia, 542: 235-247.

LUND, J. W. G., C. KIPLING \& E. D. LECREN. 1958. The inverted microscope method of estimating algal numbers and statistical basis of estimation by counting. Hydrobiologia, 11: 143-170.

MARGALEF, R. 1974. Ecologia. Editorial Omega, Barcelona. 1010 pp.

MATSUMURA-TUNDISI, T. \& J. G. TUNDISI. 2005. Plankton richness in a eutrophic reservoir (Barra Bonita Reservoir, SP, Brazil). Hydrobiologia, 542: 367-378.

NEGRO, A. I., C. DE HOYOS \& J. J. ALDASORO. 2003. Diatom and desmid relationships with the environment in mountain lakes and mires of NW Spain. Hydrobiologia, 505: 1-13.

ODA, A. C. R. \& C. E. M. BICUDO. 2006. Ecology of Peridinium gatunense and Peridinium umbonatum (Dinophyceae) in a shallow, tropical, oligo- trophic reservoir (IAG Pond), São Paulo, southeast Brazil. Acta Limnol. Bras., 18: 165-180.

ODUM, E. P. 1983. Ecologia. Editora Guanabara, Rio de Janeiro. 434 pp.

OLRIK, K. \& A. NAUWERCK. 1993. Stress and disturbance in the phytoplankton community of a shallow, hypertrophic lake. Hydrobiologia, 249: 1524.

PADISÁK, J. 1993.The influence of different disturbance frequencies on the species richness, diversity and equitability of phytoplankton in shallow lakes. Hydrobiologia, 249: 135-156.

REYNOLDS, C. S. 1984a. The ecology of freshwater phytoplankton. Cambridge University Press, London. 384 pp.

REYNOLDS, C. S. 1984b. Phytoplankton periodicity: the interactions of form, function and environmental variability. Freshwater Biol., 14: 11-142.

REYNOLDS, C. S. 1988a. The concept of biological succession applied to seasonal periodicity of phytoplankton. Verh. Internat. Verein. Limnol, 23: 683-691.

REYNOLDS, C. S. 1988b. Functional morphology and the adaptative strategies of freshwater phytoplankton. In: Growth and reproductive strategies of freshwater phytoplankton. C. D. Sandgren (ed.): 388-433. Cambridge University Press, Cambridge.

REYNOLDS, C. S. 1993. Scales of disturbance and their role in plankton ecology. Hydrobiologia, 249: $157-172$.

REYNOLDS, C. S. 1995. The intermediate disturbance hypothesis and its applicability to planktonic communities: comments on the views of Padisák and Wilson. N. Zeal. Journ. of Ecol., 19(2): 219225.

REYNOLDS, C. S. 1997. Vegetation process in the pelagic: a model for ecosystem theory. Excellence in Ecology. O. Kinne (ed.), Ecology Institute, Germany. $371 \mathrm{pp}$.

ROBINSON, J. V. \& C. D. SANDGREN. 1986. The effect of environmental heterogeneity on community structure a replicated experimental study. $O e$ cologia, 57: 98-102.

ROJO, C. \& M. ALVAREZ-COBELAS. 1993. Hypertrophic phytoplankton and the Intermediate Disturbance Hypothesis. Hydrobiologia, 249: 4357.

SHANNON, C. E. \& W. WEAVER. 1963. The mathematical theory of communication. Illinois University Press, Urbana. 125 pp. 
SIMPSON, E. H. 1949. Measurement of diversity. Nature, 163: 688.

SIVER, P. A. \& G. BASKETTE. 2004. A morphological examination of Frustulia (Bacillariophyceae) from the Ocala National Forest, Florida, USA. Can. J. Bot., 82: 629-644.

SOMMER, U. 1991. Phytoplankton: directional succession and forced cycles. In: Ecological Studies, 85: 132-146. H. Remmert (ed.). Springer Verlag, Berlin.

SOMMER, U. 1993. Disturbance-diversity relationships in two lakes of similar nutrient chemistry but contrasting disturbance regimes. Hydrobiologia, 249: 59-65.

SOMMER, U. 1995. An experimental test of the intermediate disturbance hypothesis using cultures of marine phytoplankton. Limnol. Oceanogr., 40: 1271-1277.

SOMMER, U., J. PADISÁK, C. S. REYNOLDS \& P. JUHÁSZ-NAGY. 1993. Hutchinson's heritage: the diversity-disturbance relationship in phytoplankton. Hydrobiologia, 249: 1-7.
SUN, J. \& D. LIU. 2003. Geometric models for calculating cell biovolume and surface area for phytoplankton. J. Plankton Res., 25: 1331-1346.

UTERMÖHL, H. 1958. Zur Vervollkomnung der quabtitativen Phytoplankton-Methodik. Int. Ver. Theor. Angew. Limnol., 9: 1-38.

VALDERRAMA, G. C. 1981. The simultaneous analysis of total nitrogen and total phosphorus in natural waters. Mar. Chem., 10: 109-112.

VINER-MOZZINI, Y., T. ZOHARY, A. GASITH. 2003. Dinoflagellate bloom development and collapse in Lake Kinneret: a sediment trap study. $J$. Plankton Res., 25: 591-602.

WILLÉN, E. 1991. Planktonic diatoms-an ecological review. Algol. Stud., 62: 69-106.

ZILLER, S. \& A. ECONOMOU-AMILLI. 1998. Freshwater algae from lakes in the lower Niger Delta system (Nigeria). Hydrobiologia, 368: 217-229.

ZOHARY, T., H. GUDE, B. KAPLAN, R. PINKAS \& O. HADAS. 2000. The effect of nutrients (N, $\mathrm{P})$ on the decomposition of Peridinium gatunense cells and thecae. Limnol. Oceanogr., 45: 123-130. 